\title{
Kinship Between Fairy Tale and Tragedies (a Comparative Study of the Goose-Girl at the Well Tale and King Lear's Tragedy)
}

\author{
Hafez Hatami ${ }^{1, ~ *, ~ M i n a ~ M e h r a f a r i n ~}{ }^{2}$ \\ ${ }^{1}$ Department of Persian Language and Literature, University of Payame Noor (PNU), Tehran, Iran \\ ${ }^{2}$ Institute for Intellectual Development of Children and Young Adults, Tehran, Iran
}

Email address:

Hatami.hafez@pnu.ac.ir (H. Hatami), godis_withme101@yahoo.com (M. Mehrafarin)

${ }^{*}$ Corresponding author

\section{To cite this article:}

Hafez Hatami, Mina Mehrafarin. Kinship Between Fairy Tale and Tragedies (a Comparative Study of the Goose-Girl at the Well Tale and King Lear's Tragedy). International Journal of Education, Culture and Society. Vol. 5, No. 3, 2020, pp. 53-61. doi: 10.11648/j.ijecs.20200503.13

Received: August 19, 2019; Accepted: August 20, 2019; Published: June 8, 2020

\begin{abstract}
Fairy tales are among the most important branches of popular literature. They are full of informative and imaginative themes with a simple spatial layout that have undergone changes due to the geographical range and passing of time. There are many common points between fairy tales and other literary forms because many of these stories and legends epitomize the human collective subconscious mind in terms of the origin and contents. The existence of similar narratives which originated from oral literature which often have a fun and recreative nature has provided the ground for comparative and sometimes adaptive literary studies. This descriptive-documentary study reviews and analyses the fairy tale of the goose-girl at the well by the Brothers Grimm and the tragedy of King Lear by Shakespeare. The plot consistency, the combination of tragedy and comedy, motivation, family-based, division of the kingdom, destiny and fate, the presence of superficial mysticism, the parallelism of characters, conflict and crisis and etc. are the common propositions between the two narrations.
\end{abstract}

Keywords: Folk Literature, Comparative Literature, Tale and Tragedy, Shakespeare, Grimm Brothers

\section{Introduction}

Comparative analysis and intertextuality works as a mirror to reflect the effects and exchanges between literary and artistic works. It is a tool for recognizing the exchange of cultures and ideas, and realizing the cultural similarities and originality of literary works.

The term comparative and its French equivalent comparer is taken from the Greek word comparatives; which is composed of the prefix com or cum (Latin) meaning joint and together; and the verb parer meaning to provide and equip; or the verb par meaning equal. From this perspective, two works are considered as comparative when they have two distinct cultural and linguistic backgrounds and are studied simultaneously for comparison. [1]

Comparative and contrastive literature is the result of exploring in the era of the presence of people and nations in the field of each other and the era of adaptation, trans: lation, and even violation of the literary works.

\subsection{Statement of the Problem}

In the year 1878 the World Congress on Comparative Literature in Paris, emphasized two categories and tendencies in literary criticism and comparative literature. First, the study of the artist's influence on the art and culture of a nation other than their own nation, and the other, studying the works of an artist in order to clarify those aspects affected by alien art in his works. [2]

Comparative literature working as an independent discipline in the area of comparing languages, cultures and contexts since the late nineteenth century, now is emphasizing further interdisciplinary studies.

In the present comparative study, we are faced with two genres and consequently two different audiences; therefore, more attention is paid to the common features and final conclusion instead of focusing on obvious differences. 


\subsection{Necessity and Background of the Research}

Like other products of popular and folk literature, stories have originated from among human populations in terms of source and theme. They epitomize the human collective subconscious mind, and on that basis, similar texts can be related to each other in two or more literatures. These common points may be in different parts, such as the same thing, the same subject, the same characters and destiny, and the similarity of the scene. [3] These affiliations and affinities became more perceptible in the period political and cultural domination and the era of trans: lation and adaptation.

Northrop Frye suggests four types of mythos or plot: Romantic (romance), tragic, comic and humorous (sardonic); among which comedy expresses the trans: formation and trans: ition from one community to another which is usually done through marriage; tragedy relies on the individual and the individuality of the hero, and indicates the collapse and ruin of the family or community due to the fall of the hero. [4]

Accordingly, there are two opposing literary genres in this research (one with a happy marriage and another with the tragedy of ruin) which are similar in the inner events. The importance of the comparative review of these two genres is because it provides the possibility to discover the common points of two narrations and get familiar with cultural issues and the coordinates of each literary and cultural era, and understand the influence of narrators' thoughts, trans: lations, and cultural requirements of each period on the f complexity, conflict, the beginning and the end of the story.

Many studies have been conducted in the field of comparative literature; which had valuable results, especially in the field of popular literature and children and adolescents' literature. In this regard, we can mention the following: Comparative study of works of Samad Behrangi and Shell Silverstein, Journal of Comparative Literature Studies, Summer (2008), Volume 2, Number 6; Hidden Pearls (a moral approach in a comparative study of a sample of Sobhi Mohtadi and the Grimm Brothers' Tales); Treasure of danger (the story of the Thousand and One Nights comparative study with a sample of the Mathavi Manavi and examples of the Brothers Grimm); and self-reflection in a comparative study of good and evil and two passengers of the Brothers Grimm By the authors of this article, respectively at the $6^{\text {th }}$ National Conference on Child Literature and Spirituality at Imam Reza University (AS), The $1^{\text {st }}$ National Conference of Thousand and One Nights in Bu-Ali Sina University $12^{\text {th }}$ International Conference on the Promotion of Persian Language and Literature. There are also many studies in the king Lear and other Shakespeare works, Comparison of the story of Fereydoun Shahnameh with the show of King Lear, Journal of Comparative Literature Studies, Vol. 5, No. 20, pp. 43-61. And the verse of Venice merchant Mojtaba Minavi in fifteen speeches; However, no research has been conducted with this approach i.e. comparing a tragedy in English literature and a folk tale in German literature.

\section{The Main Part of the Research}

The tale of the goose-girl at the well by the Brothers Grimm with the number of 179 [according to the website: www.grimmstories.com (3/8/2016)] which is specified in the classification of AnttiAarne under the set of romance stories, group of popular stories, is one of the works of the seventeenth and eighteenth centuries in the Friedrich von der Layen classification. [5] According to E. K. Chambers, the Shakespeare's King Lear is written in (1605-1606A. D) [6] and can be accepted as an older version of the mentioned German tale. In other words, the latter is an example of the creative reproduction of this work which changes nature from the tragic autumn of tragedy to the merry spring of the fairy tale. However, there is another belief, that the story of this play is even more ancient. Javad Peyman, trans: lator of the work, says: "At the time of people called Celt in this world, this story has been a myth of nature; because in the opinion of many researchers of legends and beliefs of these people, the word Lyre means Neptune, the farthest star of the solar system, and Goneril and Rigan, the two rebellious and ungrateful girls of King Lear mean hurricane and thunderstorm; and Cordelia means gentle breeze. Undoubtedly, thunder in nature brings nothing but destruction" [7]. It is well known that such symbolic archetypes have a considerable role in the themes of folk tales. From Roderick McGillis's point of view, since the rights and trans: formation of identity are post colonialist themes, the children literature is suitable for presenting such themes. Children's literature has always played an important role in socializing the readers. [8]

On the other hand, theater is one of the oldest arts, in addition to its cultural and perceptual dimension; it has features that deeply join the human experience and the various spiritual and supersensible dimensions of human societies. Furthermore, it has many educational and pedagogical applications, especially for children. [9] That way as soon as "the attention of the spectator is drawn into the flow of the events, all his senses are focused on and involved in this process, the senses of perception are exacerbated, his/her emotions flow freely; and in fact, the human becomes more receptive, more alert and ready to understand the unity and the hidden plot." [10] The myth also uses objective words-Indicating certain things--to describe concepts beyond the human five senses or even his primitive understanding of objects [11]. As with other species, the children's literature, as Richard Haggart says, "tends to explore and recreate and search for meaning in human experience in its best form." [8]

In children's literature, there is an educational aspect that the author attempts to convey a meaning by influencing the reader's sense of imagination, using drama, spatialization and characterization, narrating one or more events, and confronting him with a contemplative question. [12] The author tries to scrutinize the psychological characteristics of personalities and the internal capacity of events in the story. The story is the growth and evolution of the hero in the dimensions of time and place, on the basis of causality and in 
the domain of a language. Most of the terms that are used about the story, is related to tragedy, which was used by poets and play wrights centuries before the emergence of the story in its modern sense. According to Aristotle, tragedy has six main elements: plot, character, thought, diction, spectacle (scenic effect), and song (music). If we remove the two ceremonial elements of song and spectacle, three elements of the new story, which is, plot and conspiracy, character, and context, which Rene Wellek referred to in his book Theory of Literature--correspond to the same four elements of the old tragedy. Even Aristotle's notion of the climax, conflict, denouement, and the turning point of protagonist's fate corresponds to short stories, and the characters of the story are very similar to tragedy characters; but the significant difference is in the thought of the creator of tragedy and highlighting some of the actions and thoughts of the characters and inducing two instincts of fear and pity in the tragedy to the audience. It can be said that tragedy is born of predestined fate and story is born of liberty of fate. Walter Allen, the English critic, states: A storyteller makes up a second copy of human life on earth. [13] Perhaps this is because the tragedy is interspersed with reality and the story with imagination. Regardless of this, the story is a remnant of myths and tragedy is a narration of thoughts and influential kinds of plays; and as it originated from the human subconscious, it also affects the conscious and unconscious of humankind. As Freud believes: "the story trans: mits important messages to the conscious, half conscious and unconscious levels of the human mind with any degree of growth by presenting psychoanalytic personality examples." [14]

Martin Juluios Esslen writes "The effect of the show is a lot instinctive and beyond the stage of self-consciousness of the spectator." [10] In this regard, the words of J. F. Bierlein are true about the tale and tragedy studied in this paper. He says: "Myth can be part of our unconscious mind structure that probably has been encoded in our genes". [11] As a result, the audience does not need to an adventitious prognosis to understand the deep concepts of the narrative.

\section{Reading the Narratives}

King Lear wants her daughters to say how much they like him. The flattery of the older girls deceives Lear and the liberty and disgust of the truthful Cordelia of flattery, makes her real interest in father look less than her sisters; leading to his father's anger and deprivation of inheritance. Lear divides his land between his two older daughters and holds only the name and honor of the kingdom for himself. Kent's opposition to depriving Cordelia of inheritance, the loyal lord of the King Lear, results in his exile. In the third scene, when Lear comes to the Goneril palace with the noblemen of England, she wants the court chairman to show disrespect toward Lear. By doing this, she intends to take Lear's dignity. Goneril reduces the number of King's fellows to fifty. Lear goes to Regan and complains about Goneril, But Regan legitimates Goneril's behavior and reduces the number of fellows to twenty-five and Lear understands that she is also a vile like Goneril. Here begins the madness of Lear.

The scenery of the play in the entire third act, with the roar of the storm represents a chaotic universe. In a poor peasant cottage, the king is seated next to the honorable Gloucester, the loyal Kent, the clown and the naked Edgar--who plays the role of a crazy beggar--. Suddenly, it is reported that Cordelia has come to England with an army from France. With utmost trust to Edmund, Gloucester tells him that there is a tough dispute between the Duke of Cornwall and the Duke of Albania and the auxiliary force is on the way to help Lear. But Edmond surrenders Gloucester to Cornwall and Regan and the Cornwall orders to gouge out Gloucester's eyes. One of the servants resists, for saving Gloucester. Regan stabs him in the back, but the servant hits Cornwall before his death. On the other hand, Edgar decides to stay with Lear and help him; and Oswald - Goneril's steward-- receives the decree of murdering Gloucester and comes for it; but Edgar kills him in a combat. The evil girls of Lear have a bad end in the plot for hating each other. Regan wants to be Edmund's wife as Goneril. Goneril poisons him and, when her plan is revealed, takes suicide. The Duke of Albania wins the war and wants to treat Lear and his daughter Cordelia, generously; but Edmond secretly orders an officer to execute Cordelia. Finally, the traitor Edmond is seriously injured by Edgar. Edmond confesses to the secret command of the murder of Cordelia, but it's too late. Lear enters bearing Cordelia's corpse in his arms, and he dies with the hope that Cordelia may still be alive. Gloucester also dies with good reputation. At the end, Edgar becomes king!

In the tale of the goose-girl at the well, the narrative begins with an old woman in the mountains, who asks a nobleman's help to carry her two baskets filled with wild apples and pears. She rewards him a small box of unique emerald. The young man comes to the king's palace after three days of wandering and presents the box to the Queen. She falls as if dead to the ground after she opens the box. When she gets conscious, she tells the young man how the King divided the kingdom between the two elder girls, and banished the youngest with a sack of salt on her back, and two servants had to lead her forth into the wild forest. However, the king then regretted. The young man takes them to the old woman's cottage. The goose-girl who lived with her, removes the mask from the face and her beauty is revealed. The old woman disappears and the little hut turns into a palace and the geese become the servants. The nobleman marries the princess and they live in that palace until the last day of their fate.

\section{The Morphology of Narratives}

Based on the division of Vladimir Propp of the morphology of the ancient saga, the functions in the fairy tale of the goose-girl at the well are as follows:

1. The hero is called up for help and is therefore sent to a mission.

2. The banished hero is trans: ported away from home to another location.

3. The hero shows a positive or negative reaction to a person who gives him something in the future. 
4. The hero is given the chance of using a magical thing.

5. The hero moves or is guided toward something or someone who is looking for.

6. The hero arrives home or another land anonymously.

7. The wicked expels or exiles someone.

8. The one who gives the hero something in the future, requests.

9. The calamity or deficiency is healed or compensated.

10. Hero deforms.

11. The hero marries and reigns.

In addition to the above items, there are other items in King Lear, as follows:

1. The fake hero/heroes make false claims.

2. The wicked tries to delude his victim to gain control over him or things that belong to him.

3. Different characters surrender themselves to the hero whether in the form of man, animal or objects.

4. The wicked is searching for report and information.

5. The wicked injures a family member.

6. The wicked orders to kill someone.

7. The hero and the wicked combat or compete or conflict.

8. The wicked wants to force someone to marry.

9. The fake hero is scandalized.

10. The wicked is punished. [15]

\section{Story Elements}

\subsection{Plot}

"Each narrative has a story, and the storyline is guided by an intangible network of reasoning, causation and regulation of the ups and downs of the story and the encounter of the characters with them; called plot." [12] From this perspective, both texts have two parts and intricate movements; the latter begins at the middle of the first movement, - which is essentially a narrative of a third princess who is lost or searched for. In fact, in the tragedy of King Lear, the secondary plot does not mark the end of the show, but it is rather complementary to the main plot and strengthens the logical process of events; ultimately moving at the same direction with the main theme of the story. The same thing happens in the tale of the goose-girl at the well. In both narratives, contrary to the normal process of narratives with a secondary or dual plot that the hero is one person, we encounter two different heroes in both plots, secondary. Of course, the secondary plot closes quickly. Its protagonist's functions end at a heroic position and continue to play a role in the main plot; as Cordelia, the younger daughter of King Lear, as well as goose-girl, as the youngest princess, after playing the role as the hero of the secondary-plot (who is banished away from home according to Prop's morphology) plays the role of helper and princess, marrying to who is the hero's reward in the main plot. Another similarity between this tale and tragedy is the similarity of the moral characteristics of the youngest and dearest daughter of the king (the heroes of the secondary-plot). But the difference in the hero's function and the end of the main plot of the narrative is tangible. In other words, in the King Lear play, the constructive elements of narrative act synchronically, not diachronically. However, in the tale of the goose-girl at the well, the secondary character thinks simultaneously with the act of the first person. Thus, although in the King Lear play the events of story are narrated in a normal sequence; but the structure can be visualized in the form of a volumetric concept and not a flat concept in terms of geometric identity. [12]

\subsection{The Hero of the Tale and Tragedy}

In Shakespeare's masterpiece, King Lear, the father of the princess, is the hero that makes the tragedy by his tragic death at the end of the narrative. In the fairy tale of Brothers Grimm, the protagonist is a nobleman who finds the princess and makes a happy end by marrying her. The hero of the Brothers Grimm story is not as well-known as the female heroes such as Rapunzel and the Sleeping beauty or the Red Hat - thanks to cartoons and television adaptations. However, in the list of four types of literary narrative of Northrop Frye, we see the name of King Lear among some of the most famous heroes in high-level stories. [16]. In his opinion, if the hero is superior to other humans and the nature in terms of rank, the hero is a kind of romance with an amazing behavior, but on a human level. The laws of nature do not work on him. Magical weapons and talking animals and other super-natural items deal with this hero and then a legendary world will take shape; but if the hero is not superior to his surrounding environment despite being superior to other people, he is a leader. Thereby, his power is above the authority and emotions of others, but his deeds follow the natural system. This hero is the hero of epic and tragedy. [17] In other words, "the hero of the tragedy is between two angelic and human spaces." [18] For the same reason, in the story of the Grimm Brothers, the madness of the king's father does not occur; because only King Lear is supposed to gain deep self-awareness and self-knowledge within his madness which brings him to death or another birth. The hero of the tale, like the hero of the myth, faces threatening forces and quizzes, sometimes magical forces help him, and he is rewarded after having to bear a lot of hardship. The victory may appear in the form of a marriage to a goddess-mother of the world (Holy marriage) or as acceptance at the creator's-father's port (reconciliation with the father) and the last action is the return of the hero; i.e. in the story of the goose-girl at the well, by reconciliation of the princess with her father and her return the tale ends. Of course, if we look at Edgar's reign in the King Lear play as a reward in Prop's attitude, he can also be the third hero of this narrative; thus, unlike the common tragedy, it brings a good end to the story. However, basically the problem is that Edgar is not Shakespeare's protagonist and the title of this tragedy and the tragic atmosphere of the narrative confirm this.

Looking at the common point of both narratives, where the King's youngest daughter plays the role of the banished hero; the frivolity and the violence of the old kings causes the young girls to face an uncertain and vague fate; but contrary to the simplicity of the tale of the Brothers Grimm, all details of events are recorded in King Lear, "as the tragedy is to pay 
attention to the partial attributes and expressions of moods and manners and the complex spirit of heroes." [3] We have more information about what happened between Cordelia, her sisters, Lear and his wife, and the French Duke. Also, death of Cordelia, along with his father's death, has added pain to the tragedy, which is at the opposite point of the goose-girl's marriage and happiness and return to her parents and the royal crown at the end of the tale of the Brothers Grimm. However, the young prince in the tale of the Grimm Brothers compared to the French Duke--who has the role of the Heroine's husband - although both are descendants of the kings, but the French Duke's undying and pure love for Cordelia in King Lear is more evident, and he wants and chooses her as she is, despite being rejected and deprived of the divisions of the lands and the dowry. And in the tale of the Brothers Grimm, the young prince is the one who accompanies and helps the landless king and his wife to find their rejected daughter. being support is a common feature of these two men. Therefore, the role of these two young people cannot be ignored in advancing the course of the fate of the heroine.

\subsection{Character, Characterization, and the Functions of Dialogue}

"In characterization, the author usually works in two ways: either uses pre-made and established characters in folklore culture and narrates their stories or creates new characters according to the intended themes." [19] The first method is used to write tales by Brothers Grimm's, but Shakespeare in King Lear created unique personalities with different spirits and sometimes complex versus simple characters, but with deep attitudes and inner descriptions which seem difficult to understand by a child and teenager. "In the children literature, characters are less trans: parent than the whole of literature; because the author tends to focus on external personality rather than internal; and the exterior description of a character is the easiest tool the author uses. [By doing this] he gives the reader a straightforward image of the literary character." [8] However, what makes a character seem superb is his/her viewpoint and interaction with the world. The protagonist is the spirit of the story. Defective or unique, full of love and affection or anger and hatred, the hero of the story must be memorable and evolving. This is the dimension that distinguishes the structure of lasting tales from other narratives; which in both cases under this study, the creator of the work has paid attention to this issue. Although in the short story, there is often not an opportunity to characterize, but one of the most commonly used methods of characterization in the stories of the Grimm Brothers is explicit characterization by explaining them explicitly and directly. In other words, the whole omniscient narrator introduces the characters to the audience by describing the behavior and actions of them. In this way, it provides the basis for the subsequent actions of the characters and then the protagonists present themselves with more features during the actions and reactions and conflict with other secondary characters and they reveal their hidden layers. In such a situation, using dialogue is an applied method for characterization, in order to better understand and expand the protagonist of the story. Naturally, in the play, dialogue is the main component and the basis for the introduction of characters. Particularly dramatic talk provokes discussion, strong emotions, or conflict between characters. [20] Shakespeare's play with a long structure has also been able to have a successful and impressive impact on the audience by using dramatic conversations. For example, in a scene that starts with the arrival of Kent in regular clothes with Lear; Kent wants to protect Lear from the consequence of his unwise manner. Clown gives a hat to Kent. Kent asks: For what? and the clown replies: because you are beside someone who is exposed to the wrath of others. Then the clown gives Lear the hat with laughter. King Lear threatens him with a whip. The clown in response to Lear's threat says: The truth is that the dog must go to his bed and when his wife stays near the fire and smells the stench, the dog must be pulled out with a whip. Then the clown sings a chant about a sweet clown and a bitter clown: be richer than you show people, speak less than you know, borrow less than you have, ride more than walking, learn as much as you think you know, gamble less than the amount you hope to win.... Clown calls Lear a clown and talks to him bitterly: You were a perfect man, but now you are like a zero, without any number in front of it. Now, my situation is better than you; because I am a clown, and you are nothing.

This conversation between Kent, Clown and Lear and especially the clown's bitter quotation refines the spirit and soul of the audience and makes him think and reflect, and extract as ooze from all the drama. It affects the depth of the audience's feelings and thoughts (not just the viewer) thundering by breaking down the boring narrative story by the rhythm of storm words just like the terrible sound of the storm on the stage.

A remarkable point in the Brothers Grimm's story is narrating part of the story by Queen (Mother); a secondary character who is not seen in King Lear's tragedy. "And thus, by changing the narrative point of view--indirect presentation of the information about the story and the protagonist--plays an important role in narrative by displaying the behavior, manner, thinking and speech of the protagonists." [12] Part of the narrative: the queen cried, I had three daughters, the smallest of them was so beautiful that had a face like a white snow and red blooming apple and bright hair like sunlight and everyone who visited her were dazzled. When she cried, pearls would flow out of his eyes instead of tears. When she was fifteen, the king summoned his three daughters and said: since I do not know when I will die, I want to announce my will; and each of you has more affection for me, will have more share. So tell me to know how much your love is. The little girl stayed silent and said, I cannot compare my love with anything, but on the insistence of his father, she said: The most delicious things without salt are tasteless for me. So I love you as much as salt. The king got angry and said: your share will be the same salt and then divided his land between his two older daughters.

On the other hand, the words of the old woman are valuable and sometimes proverbial. For example, in a conversation with the nobleman: Don't look behind you, You will only see 
how crooked your back is!

Who knows what good there may be for you?

She said to the goose-girl: Go into the house, my dear daughter, it is not good for you to be alone with a young gentleman; one must not pour oil on to the fire, he might fall in love with you.

To king and queen: You, however, have been sufficiently punished by the misery in which you have lived.

The King said: "My dear child, I have given away my kingdom, what shall I give thee? -She needs nothing, said the old woman. I give her the tears that she has wept on your account; they are precious pearls, finer than those that are found in the sea, and worth more than your whole kingdom, and I give her my little house as payment for her services." [5]

Another point is the conflict of the character of the king in both narratives, which in King Lear, all its instances, including his inner struggle with himself, with others, with society, all its rules and norms, and even with nature. [12]; However, in the tale of Brothers Grimm, this conflict is not so intense.

In the analysis of Shakespeare's tragedy characters, King Lear's ignorance maximizes when he asks the daughters to say how much they like him. Lear's larger illusion is where he thinks: Imperialism is born with a person and accompanies him to the end of his life. He thinks he can forgive his land and his power and, at the same time, be respected as a king. He gives the real power away and is delighted with formal power. (He is the protagonist; the hero of the original plot or the first movement; gray, dynamic, multi-dimensional, immersive and introspective, introverted) and inspirational (intuitive introspection), that maybe so intuitive as to have little relevance to reality. They are dreamy, imaginative and unconventional and find planning for the future difficult. [21]

The clown has been described less as a character and more often as a type, but he actually expresses the inner voice of King Lear loudly. The clown is a wise person who knows exactly what he says and what he does; but pretends to ignorance. His bitter humor creates job security for him. On the other hand, he points out the atrocity of the privileged classes and the noblemen to Lear by being a simple and ordinary human. In this way, he tries to inform the King of injustice in the society and to make him aware of the situation of the poor and the destitute people ( $\mathrm{He}$ is a secondary character/implicit, Contributor, White, Static, Flat, Typical, Introspective Thinker) The intellectual introverts do not have a good compatibility with others, they have difficulty expressing their thoughts, seem unemotional, do not pay attention to others. They are not about feeling, but on their own thoughts. [22]

The older girls, namely, Goneril and Regan and Duke Cornwall, the Reagan's husband, have identical characters. Duke Cornwall, like his wife, is a villainous and evil character; to the extent that gouges the eyes of Lord Gloucester with his hand. (They are secondary, evil, static, flat, black, typical, extroverted thinkers); this type of character live according to rigid rules. They suppress their feelings and excitements; they are realistic in all aspects of life. [21]

The Duke of Albania, the husband of Goneril, is a bad man.
(He is secondary, antagonist, evil, black, static, flat, allegorical, introspective extravert character).

Edmond, the illegitimate and traitor son of Gloucester, is a primitive man. He has an inhuman attitude towards the world and human beings which forces him to destroy the other, in order not to endanger himself. In his view, all the right and good personalities are victims and foolish (he is a secondary, black, static, flat, allegorical, introspective extravert character); The inspirational/intuitive extravert type is highly effective in business and politics because of its ability to exploit opportunities. They are fascinated by new, changeable, and creative ideas. Most magicians and wicked people in the tales of the Grimm Brothers are in this group.

Cordelia, the little daughter of Lear, is intimate, kind and honest and lovely (she is the secondary/opponent, protagonist in the secondary plot of the tragedy, white, static, flat, allegoric, extravert emotional character). An emotional extravert is an inhibitor of their thoughts and is extremely emotional. They follow the values, ethics and traditions that they have learned and are unusually sensitive to the expectations and beliefs of others. Most women have this personality brigade. [22]

The most prominent secondary character of this play is Lord Gloucester, who, like Lear, is a fast-paced, angry, idiotic and timid man who makes mistakes in judging his children (He is a white, static, flat, allegorical, extravert and emotional character).

But Edgar, the Gloucester's real son, is superficial. He is young and can tolerate suffering. He does not surrender. At the beginning, he is alone and disturbed, but on the drama track he finds his abilities in the presence of the other sufferers (he is a secondary, white, static, one-dimensional, all-round, extroverted-emotional character).

Lord Kent, the Faithful to King Lear, is a simple, brave and loyal person. (He is Secondary/ confidant, contributor, white, static, flat, allegorical, extravert thinker character).

In the study of the characters in the tale of the Brothers Grimm; the witch (wise woman) is the Princess's helper in the trans: fer, refuge and deformation; she is beneficent toward the young nobleman; by asking for assistance in doing difficult work: carrying her heavy baskets without stopping until reaching the cottage; and rewarding him the magnificent palace with the servants. She is secondary, white, static, flat, conventional, and extravert emotional character (punctilious in dealing with people and sympathetic to the girl banished by the king).

Young gentleman is the hero/protagonist; white, static, flat, kind and allegorical (modest toward the old woman), emotional extravert (sensitive to the opinions of the old woman about aristocrats and noblemen).

Goose-girl is the princess, the hero (in the second move of the story: banished from the palace) and the missing person (marrying her is the reward of the protagonist of the first plot of the tale), secondary, white, static, flat, allegorical (beautiful and submissive), extravert and emotional (she is emotional and sensitive in treating her father; years of crying for the rejection by the one who loves; adhering to the rules and 
obedience of the old woman).

The King; the father of three daughters, is wicked (in the secondary plot of the tale), sending a gentleman to search for his daughter (in the first move (plot) of the tale). He is secondary, gray, dynamic and multidimensional, (his attitude has changed over the story to the true affection of his daughters, as well as his reaction to his younger daughter), typical, extravert thinker (suppressing paternal affections towards the younger daughter).

Queen is a Secondary, white, static, flat, typical, extrovert-emotional character.

\section{Awareness, Subconscious, Archetypes and Symbols}

The purpose of a ritual ceremony, like the play, is to reach a higher level of consciousness, to receive a significant insight into the nature of existence and the reconstruction of the human being and the ability to move in with the so-called dramatic world, cultivation, and refinement, or communication and illumination and inner light in religious terms. [10] Delachaux believes: if father's disregard for the girl shows the unconscious and reactionary nature of the old king, there are other indications that, despite this disregard, there is a solid link between the princess and the king (a person's unconscious and collective subconscious) and that is the interest of the girl to her father; the interest is often the same as the Oedipus complex. A complex that is a central issue in childhood, and in psychology it is a form that appears especially at the age of four and five, when the girl is much interested in her father, and hates mother; the same happens in boys in the opposite direction. [14]

The princesses who sacrifice their lives in the love of their father are abundant in myths and stories. Only in this story there is the fury and wrath between father and daughter. This story tells us that the anger and disagreement arose from the fact that the princess did not know and could not express her love to the father in a brilliant way. Perhaps this exceptional case should be regarded as the display of the fate of the astrological images of the constellation which are so excited about individualism and close to self-awareness that they can not reveal the memory of the world; and the old king denies them and rejects them because he recognizes that they are not aligned with him. [22]

In the following, the rejection of the girl with two bags of salt on her shoulder, illustrates its symbolic function; as salt is a symbol of cleansing, preserving, purifying the body and soul, it is non-corruptive and sign of loyalty and catharsis. It was used because of its nature in most religions rituals such as Christianity and baptism. However, it may also be used in the opposite sense, that is, fertility. The punishment and suffering--which is in some cases attributed to salt--is secondary. [23] In any case, it complements the concepts of the next symbols. Even when the old woman sends the daughter to tend a flock of geese, it has a symbolic look to goose. The goose is a symbol of intelligence and knowledge, but the migrating habit of this bird has made it a symbol of separation and nostalgia for the home. The princess reaches personality independence and a higher perception of life in this parting and being away from parents. [24] Somewhere else in the story: the girl went to the well next to which there was three old oak trees, picked up her mask and washed herself. Suddenly she heard the scratching of the leaves of the trees. [5]

The oak tree was one of the most sacred and worshiped trees in many societies throughout Europe, and people believed that the sound of the leaves of this sacred tree can foretell the future [24]. So it seems that something is going to happen. The old woman and the girl are busy spinning when the old owl stares out the window and says three times: Uh-huh... The old woman says, do you know what the time is? The girl says, It's almost midnight. The old woman says, did you forget that you are living with me for three years now? Opportunity is over. [5] In addition to this, the owl is a symbol of intelligence and cleverness, and in the renaissance parables it is the embodiment of night and sleep. [24] According to Delachaux, the existence of an old spinner woman, who is also referred to in the famous Sleeping Beauty tale, has the role of a mentor who is responsible for teaching the beautiful girl who is disturbed by puberty changes (In the narrative the queen mentions that the princess was fifteen years old when she was banished away from the palace). In fact, the old woman gives the young girl a spindle which is a sign of male genitalia. This is important; because in the primitive tribes, the elderly teach customs and traditions to children, not the parents of children. Also, in redefining the semantic meaning of yarn in a secular world, it is introduced as a symbol of sexual intercourse, and the hasp and the spindle are symbols of the strings of life and secret understanding, the continuity and survival of life or the survival of the human species, in myth and story. [22]

Repeated references to the number 3 throughout the story (the third daughter, three years old with an old woman, three days of wandering in the desert, three oak trees, three times owl's voice, three daughters of Lear, and Lear's struggle in three first scenes with girls, $t$ reminds that psychoanalysts are convinced by studying the dreams that the digit three is a sign of sex and the symbol of a couple who breed; and it is among the mystical triplets, which is a symbol of the Father; the Holy Spirit, the Virgin mother and the Son and it is the basis of the religions of the world and, above all, the religion of Mithraism. Based on this discourse, the interpretation of number three is: materiality, spirituality, and theology; in other words, it describes the three stages of human evolution. [22]

It is clear that the literature of children and adolescents in a special sense was first found in the mid-eighteenth century and in England which was rooted in industrial growth, the emergence of the new middle class and the expansion of formal education among other countries in Europe and the world. Subsequently, the countries of North Europe, especially Germany, paid attention to children's literature I the country and it had an educational and teaching orientation before the Enlightenment era; in this age the issue of teaching and studying children literature became important and great 
thinkers like John Locke and Jean-Jacques Rousseau put new ideas about children's issues. [25] However, it is not far-fetched that such a narrative-which undoubtedly is rooted in an old pattern-, has been issued to other narrations in other countries of the world from the Shakespeare's tragedy of King Lear and deliberately initiates an intersection between tale and tragedy.

\section{Conclusion}

In the tragedy of King Lear and the tale of the Gosse-girl at the well; except the king all characters are static and flat. Wickedness and blackness shadow over more than fifty percent of Shakespeare's tragedy characters, while this figure is twenty percent in the Brothers Grimm's tale. Ninety-nine percent of the characters in this tragedy and all the characters in this story are extrovert. About half of the characters are allegorical and the other half are typical. There is only one contractual character in the tale of goose-girl at the well. The plot consistency, the combination of tragedy and comedy, motivation, being family-related, division of the kingdom, destiny and fate, the presence of superficial mysticism, the parallelism of characters, conflict and crisis and etc. are the common propositions between the two narrations. Although the issue of evolution and catharsis happens in Shakespeare's tragedy for King Lear and Cordelia is the most effective victim of this bitter story, but in Brothers Grimm's tale, the physical, moral, mental and sexual maturity occurs for girls as a happy lucky hero. However it seems that: in Shakespeare's belief, those who adhere to spiritual values, although not always victorious, have the special ability to emancipate from misery. By the end of the play, Edgar will reign, thanks to the fate and shows that Shakespeare hopes for the ultimate victory of humanity. So if we ignore the main character or hero of King Lear and look at this tragedy from another perspective, a happy ending has come about such as myths and tales, which is the desired moral result of Shakespeare. Despite the fact that the Grimm Brothers tale seems to be an example of the creative re-creation of Shakespeare's play, attributed an older background to the myths of the Celtic people (about the planet Neptune and the elements of nature, the storm and the Thunder and the breeze) which is matched with Delachaux's theory of displaying the fate of astronomical images and the celestial. In this way, both Brothers Grimm and Shakespeare in addition to understanding the encoding of stories, legends and myths had a pedagogical attitude to symbolize the past, and have been struggling to promote morality and human values by selecting some distinctive characters. On the other hand, regarding the effect of theater therapy. and the effect of stories on the child's unconscious, that's fine if contemporary playwrights, especially in the theater of children and adolescents, bring some of these stories to the theater - which are more concise than plays with difficult conversations for children and adolescents -and allow the children to have a share of the famous tragedy in the words of the childish narratives.

\section{References}

[1] Namvarar motlaq. Bahman. (2008) Comparative knowledge (Daneshhay tatbiqi) (Researches). Trying to Kangarani. Manizheh. Tehran: Sokhan. Pp. 19-24.

[2] Mohammadi. Ebrahim (2007) Theoretical Foundations of Persian-Arabic Comparative Literature (Mabani nazari adabiat tatbiqi farsi- arabi). Birjand. Qohestan. Pp. 42-43.

[3] Islami Nadushan. Mohammad Ali. (2012). World Cup Viewer (Jam è Jehanbin). 3th ed. Tehran: Qatreh. Pp. 349, 90.

[4] Depil. Elizaneth. (2008). Plat (peyrang). trans: Masod Jafari. Tehran: nashr Markaz. p. 127.

[5] Grimm. W. C \& Grimm. J. L. C. (2005) Grimm Brothers Tales and Legends. trans: Riahi. Hormoz (two vol). 2th ed. Tehran: Paykan. Pp. 979-996, 853-862, 859.

[6] Brackett. O. G (2010). The history of World drama. Trans: Azadivar. Hoshang. Fifth ed. Tehran: Morvarid. p. 348.

[7] Shakespeare. William. (2003). King Lear's. trans: Javad Peiman. 9th ed. Tehran: intesharat ilmi va farhangi. P. 11.

[8] Hunt. R. Peter. (2008) Other Inevitable Readings: Critical Approaches and Theory of Child Literature. trans: KHosrowNezahd, Morteza Digar khanihay è nagozir (roykardhay è naghd va nazary Kodak). 1th ed. Tehran: Kanon parvaresh fekri Kodak va novjavan. Pp. 392, 127, 561.

[9] Amini. Rahmat. (2011) Pedagogical theater. (educational) [Principles and Criteria $=$ mabani va meyarha]. 1 th ed. Tehran: Afzar. Pp. 11-15.

[10] Esslin, Martin (2003). What is the play? Trans: Shirin khaleghi. 4th ed. Tehran: Nomayesh. Pp. 65, 64, 33.

[11] Bierlein, J. F. (2007) Parallel myths (Ostorehay è movazi). Trans: Mokhber. Abbas. Tehran: Markaz. Pp. 12, 10.

[12] Biniaz, Fathollah (2015) An introduction to fiction writing and narrative (Daramadi bar dastan nevesi va ravayat shenasi). 6th ed. Tehran. Afraz. Pp. 16, 18, 19, 132, 27.

[13] Baraheni, Reza (2014) Writing Tales (Qesse nevisi). 6th ed. Tehran: Negah. Pp. 118-128.

[14] Bettelheim. Bruno (2014) The uses of enchantment trans: (kodakan be qesseh niaz, Behrouznia. Kamal). 3th ed. Tehran: Afkar. Pp. 17, 64, 227 \& 23.

[15] Propp. Vladimir (2013) Morphology of Fairy Tales (Rikht shenasi è qessehay è parian). Trans: Badrai. Feraydon. 3th ed. Tehran: Tous. Pp. 81-129.

[16] Cope. Lawrence (2011) Myth (Ostoreh). Trans: Arzpeyma. Abbas. Tehran: Neshaneh. p. 177.

[17] Frye, Northrop (2009) Anatomy è Tragedy. Trans: Avliai. Hellen. 1th ed. Isfahan: Farda. Pp. 10-12, 47-48.

[18] Maraknezhad. Rasoul (2014) Myth and Art (Ostoreh va honar). Tehran: Mirdashti. p. 289.

[19] Salajegheh, Parvin (2008) From this oriental garden (Az in bagh sharqi). Tehran: Kanon parvaresh fekri Kodak va novjavan. p. 42. 
[20] Mirsadeqi. Jamal (2015) Elements of the story) Anaser è dastan 9th ed. Tehran: Sokhan. Pp. 125-128. \& Rojani. Lisa\& Economy, Peter (2014) Fiction for children (Dastan nevisi baray è kodakan). trans: Kazemimanesh. Sara. 4th ed. Tehran: Avand è danesh. Pp. 133-137.

[21] Schultz. Duane \& Schultz. S. E (2008) Personality Theory (nazaryye shakhsiat). Trans: Karimi. Yosof. 1th ed. Arasbaran: Tehran. Pp. 110-111.

[22] Delachaux, M. Loeffler (2007). The secret language of fairy tales (Zaban è ramzi è qessehay è parivar). Trans: Sattari. Jalal. 2th ed. Tehran: Tous. Pp. 114-116, 185-187, 220-224.
[23] C. Hevallier G \& Allen. G (2009) The Encyclopedia of Nomads (Farhang è nomad) vol 5. Trans: Fazayeli. Soudabeh. Tehran: Jeyhoun. Pp. 448-452.

[24] Hall. James (2014) Ethnography in East and West Art (Farhang è negarai è nomadha dar honar è sharq va gharb). Trans: Behzadi. Rofayyeh. Tehran: Farhang è moaser. Pp 70, 280, 42.

[25] Pouladi, Kamal. (2008) Children's Literature Foundation (Bonyadhay è adabiat Kodak). 2th ed. Tehran: Kanon parvaresh fekri Kodak va novjavan. Pp. 70-78. 